25. Miyo Y. Knowledge-Gap Hypotheses and Media Dependency / Y. Miyo // R. N. Bostrom (Ed.). Communication yearbook. Vol. 7. - Beverly Hills : Sage, 1983. - P. 626-650.

26. Pompe H. Zeitung / Zeitschrift // Handbuch Medien und Literatur / Hrsg. u. Einl. v. N. Binczek u.a. - Berlin ; Boston : der Gruyter, 2013. - (Reference). - S. $294-310$.

27. Röper H. Zeitungsmarkt 2014: Erneut Höchstwerte bei Pressekonzentration. Daten zur Konzentration der Tagespresse in der Bundesrepublik Deutschland im I. Quartal 2014 / H. Röper // Media Perspektiven. - 2014. — Heft 5. — S. $254-270$.

28. Schenk M. Medienwirkungsforschung / M. Schenk. — Tübingen : Mohr, 1987. — 493, (XII) S.: Tab., Zeichn.

29. Schrag W. Medienlandschaft Deutschland / Hrsg. v. Bayer. Landeszentr. Für politische Bildungsarbeit (München) ; Red.: Dr. P. März, M. Franz. - Konstanz : UVK, 2007. - 381 S.: Ill., dar. farb.

30. Schröder H.-D. Zeitung / H.-D. Schröder // Medien von A bis Z / Bundeszentr. für polit. Bildung; Hans-Bredow-Inst. für Medienforschung; Einf. v. U. Hasebrink. — Wiesbaden : Verl. für Sozialwissenschaften, 2006. — (Schriftenreihe; Bd. 564). — S. 399-401.

31. Schulze V. Die Zeitung: Ein medienkundlicher Leitfaden / Teilw. hrsg. v P. Brand. - 1., völlig überarb. Neuaufl. — AachenHahn : Hahner ; Braunschweig : Westermann, 2001. — 396, [6] S.: Phot., Zeichn.

32. Weber M. Rede auf dem ersten Deutschen Soziologentage in Frankfurt 1910 / M. Weber // Gesammelte Aufsätze zur Soziologie und Sozialpolitik / Vorw. v. Mar. Weber. — Tübingen : Mohr, 1924. — S. 431 449.

33. Wirtz B. W. Medien- und Internetmanagement / B. W. Wirtz. — 8, aktualis. u. überarb. Aufl. — Wiesbaden : Springer, 2013. 930, (XVII) S.: Tab., Zeichn.

34. Witt U. Vorstellung der Werbeträger / U. Witt // Werbeträger: Handbuch für die Praxis des Werbeträgereinsatzes / H. Fischer, K. Goschmann, H. Großmann u.a.; Hrsg. u. Vorw. v. J. Ruland. - 5. Aufl. — Bad Homburg : Verl. für Marketing, 1979. — S. $65-109$.

\title{
George Bogdanov \\ Newspaper as a source of gratification of the information needs and as an object of the soological studies
}

An article is a interdisciplinary work, it is at the junction of the record keeping, of the theory and history of press and of the general and applied sociology written and has to the study of newspaper devoted. An author give the most known definitions of newspaper, every in the course of last century developed. The fundamental subjects of the article are a description of newspaper as a produkt of the print, that is aimed to satisfy the information needs of the spokesmen for the various age groups, ananalys is of rating of the newspaper as the source of information and a coverage of main tendencies in the interdisciplinary researches, why special attention is given to sociological aspects of similar researches. An article sums up of study of the development of the modern newspaper as a separat form of the print works beginning from the 1900s to the 2010s, as large classifications of the newspapers had maked. Moreover, is a comparative description of the magazin and newspaper as 2 separat forms of periodical press and objects of the applied sociological researches in the article described. By the study of original sources, that were published over the last 40 years, is established, that in consequence of the digitalization and appearance on the market Internet-versions of different publications reduces a rating of the usual printed newspaper gradually by numerous groups of population, in the first place by the young at the age under 30 years, including by students and by persons, who receive their vocational training. This problem remains unresolved and asks subsequente laborations in the field of study informationneeds of different categories of readers - as representatives of the native population as the numerous groups of the migrants and refugees, who gets to Germany from the 1950s.

Keywords: newspaper; classification; function; information need; reading; popularity; interdisciplinary research; sociological research; migration; tendencies of development

Надійшла до редакції 5 листопада 2019 року

\section{QD 3 АРХІВУ КНИЖКОВӦ̈ ПАЛАТИ УКРАЇНИ}

\author{
УДК 002.1:908(477.411)]"1918"(045) \\ DOI: $10.36273 / 2076-9555.2020 .1(282) .44-48$
}

\author{
Лариса Дояр, \\ кандидат історичних наук, доцент, \\ старший науковий співробітник Книжкової палати Украйни, \\ e-mail:arkhiv@ukrbook.net \\ ORCID: https://orcid.org/0000-0003-0789-2462
}

\section{Київ у друкованих виданнях 1918 року}

Пропонована розвідка змістовно й концептуально належить до досліджень з історичного краєзнавства м. Києва. На тлі критичного аналізу періоду револючій, Першої світової та громадянської восн авторка проводить огляд друкованих видань 1918 р., присвячених різноманітним аспектам тогочасного життя столиці. У статті використано книгодруки, що зберігаються в архівних фондах Книжкової палати України. Поміж них такі раритетні видання, як путівник Києвом, укладений відомим українським істориком К. Широцьким, наукові праці украӥнського мистеитвознавия Ф. Ернста та історика В. Прокоповича. Зазначені видання констатують культурні здобутки Києва, демонструють їх в історичній ретроспективі, актуалізують проблему збереження пам'яток. 3 особливою гостротою постає питання революиійного вандалізму, коли внаслідок гарматних обстрілів та вуличних боїв гинуть безцінні художні твори, предмети прикладного мистечтва, оригінальні артефакти повсякденного побуту. Спираючись на вітчизняні друковані видання 1918 р., авторка аналізує жахливі втрати унікальних художніх цінностей, зокрема приватних колекцій М. Грушевського та В. Кричевського. Наявні в архівному фонді історичні праџі віддзеркалюють поширену на той час тенденцію щяодо їх популяризації серед (c) Дояр Л., 2020 
різних верств суспільства. Надзвичайно інформативним у контексті розвитку києвознавства є кишеньковий (адреснотелефонний) довідник "Весь Київ" 1918 р., щуо віддзеркалює різнобарвне й повночінне обличчя столиці, починаючи від державних органів влади й закінчуючи дрібними питаннями приватного життя пересічного киянина.

Ключові слова: історико-культурний довідник; художні скарби Києва; приватні мистецькі колекціӥ; революиійний вандалізм; традиції столичного самоврядування; адресно-телефонна книга

Постановка проблеми. Буремні роки столітньої давнини, пов'язані з революціями 1917 р. і подіями Першої світової та громадянської воєн, позначилися на житті стародавньої столиці України. Київ, що виник на початку раннього середньовіччя й у своєму розвиткові пройшов усі етапи європейського цивілізаційного становлення, мав власну, цілком оригінальну, рефлексію на все, що відбувалося навкруги. У книжковому фонді Державного архіву друку зберігаються вітчизняні друковані видання 1918 р., у яких йдеться про тогочасне суспільно-політичне, соціально-економічне та культурне життя Києва.

Аналіз попередніх досліджень і публікацій. Icторіографія київської тематики неосяжна, адже дивне місто на пагорбах, розташоване повздовж величного Дніпра, цікавило значну кількість авторів, починаючи від доби раннього середньовіччя. Серед сучасних дослідників києвознавства варто виокремити таких пошуковців, як В. Киркевич, Д. Малахов, С. Тараненко, Ю. Мисько, О. Зажигалов та інших. Хронологічно близькою до цієї розвідки є книга С. Машкевича "Київ 1917-1920 pp." [4].

Метою статті $є$ аналіз вітчизняних друкованих видань 1918 р., присвячених Києву, що зберігаються в архівному фонді Книжкової палати України.

Виклад основного матеріалу дослідження. Звертаючись до історії, зауважимо, що 1918 р. був надзвичайно багатим на події державного будівництва: на його початку, 9 січня, проголошено Четвертий (самостійницький) універсал Української Центральної Ради (УЦР), згодом, 29 квітня, в останній день свого існування, УЦР проголосила Конституцію Української Народної Республіки (УНР), того самого дня внаслідок державного перевороту до влади прийшов гетьман Павло Скоропадський i, врешті-решт, уночі $з$ 13 на 14 листопада було утворено Директорію, що стала органом антигетьманського повстання й відновлення УНР.

I це лише національний сегмент тогочасних подій. Не слід забувати, що наприкінці січня 1918 р. владу в Києві захопили більшовики, а на початку березня того самого року до столиці увійшли німецько-австрійські "визволителі". Ці події відбувалися на тлі різноманітних, протилежних за своєю суттю, суспільних реакцій. Зокрема, на захист Української Центральної Ради стали герої Крут, а на боці більшовиків виступили робітники столичного заводу "Арсенал". Щодо суспільного ставлення до військ німецького генерала Г. Ейхгорна та його австрійського колеги Е. Бельца, то в лоні ініціаторів їх приходу - уряді УНР спостерігалося нетривале в часі задоволення, саме до того моменту, як "союзники" ініціювали державний переворот і прихід до влади гетьмана Скоропадського, а столичні симпатики більшовиків до появи німців $\mathrm{i}$ австріяк у Києві були налаштовані вороже.

Згодом неприйняття німецько-австрійської присутності на наших теренах на певний час об'єднало за- пеклих супротивників - національні сили, що відстоювали УНР, і більшовиків, які боронили радянську владу в Україні. Результатом цього маловідомого дотепер політичного альянсу стало більшовицьке фінансування антигетьманського повстання в Києві, про що в політичній еміграції розповідав член УЦР М. Шаповал. Звинувачуючи одного з лідерів Директорії, колишнього голову Генерального секретаріату В. Винниченка в тому, що він взяв гроші у більшовиків для повалення влади Скоропадського, М. Шаповал наголошував, що на знак протесту відмовився працювати в Директорії.

Цікаво, що книговидавничий Київ - як центр найзапекліших баталій у боротьбі за владу - на зазначені події реагував доволі спокійно. Впродовж карколомного 1918 р. столичні видання продовжували друкувати заздалегідь написані рукописи. Зокрема, видавництво В. Кульженка підготувало путівник Києвом (автор К. Шероцький, він же відомий український історик К. Широцький), у якому, окрім багатющого текстового матеріалу, було уміщено план міста та 58 ілюстрацій [6]. Книга загалом налічувала 356 сторінок. Головним пунктом iї продажу стала книгарня Л. Ідзіковського, розташована на Хрещатику.
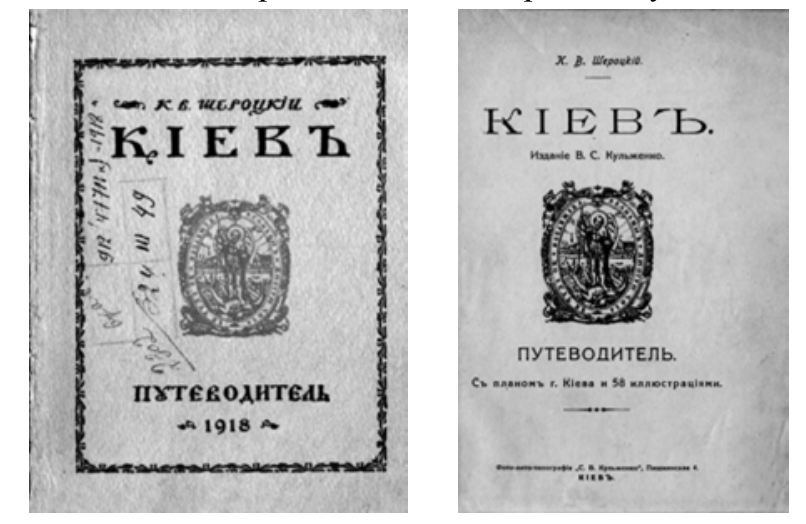

Путівник видано на якісному папері, позначено емблемою архістратига Михаїла та присвячено легендарній знавчині в галузі мистецтвознавства П. Гудаловій, що була близькою людиною і для автора, i для видавця. Дружина видавця путівника й колега по цеху автора Поліна Кульженко (Гудалова - iї сценічне прізвище) відома насамперед тим, що працювала директоркою Київської картинної галереї під час гітлерівської окупації столиці й складала списки на вивезення художніх цінностей до Третього Рейху. За радянських часів іiі звинувачували і у причетності до зникнення славнозвісної Бурштинової кімнати. За перелічені гріхи жінку було засуджено й ув'язнено у таборах вона провела майже 10 років. Після звільнення жила в російському місті Кострома, де працювала мистецтвознавцем.

Не менш цікавою є й авторська постать - історик Костянтин Широцький залишив по собі велику кількість наукових праць, зокрема розвідку "Коліївщина", що також зберігається на полицях архіву Книжкової палати України. 
У передмові до путівника, датованій 18 липня 1917 р., зазначено, що видання призначено для тих, хто прагне побачити Київ "зі слідами художнього смаку", Київ, "пов'язаний 3 видатними явищами культурного життя в минулому і теперішньому". Автор не претендував на цілковиту повноцінність викладу, через що радив читачам звертатися до фундаментальних праць, зокрема досліджень митрополита Свгенія, пошуковців Д. Айналова й Е. Рєдіна (Софійський собор), І. Фундуклея (стародавні артефакти Києва), М. Закревського (опис давнього Києва), В. Антоновича (монографія, археологічна карта Києва), П. Лашкарьова (церковно-археологічні нариси), М. Сементовського, І. Толстого, Н. Кондакова (давньоруські київські пам'ятки), М. Захарченка (розповідь про Київ), М. Петрова (топографічний нарис давнього Києва), Я. Смірнова (малюнки старого Києва), В. Іконнікова (Київ у 1654-1874 рр.). По суті, К. Широцький навів грунтовну бібліографію 3 обраної теми, укладену на момент написання книги.

Історичний нарис путівника складався 3 п'яти розділів:

1. Старе місто - описи таких об'єктів, як Золоті та Львівські ворота, церкви Святого Георгія та Святої Ірини, Десятинна та Андріївська, Трьох Святителів та Різдва Христова, Софійський собор, Михайлівський монастир та монастир Дмитра і Петра, Брама Заборовського, Софійська та Михайлівська площі, Володимирська гірка та інші [6, с. 10-127].

2. Поділ - описи таких пам'яток: Пам'ятник хрещення, Олександрівський узвіз, Києво-Могилянська академія, Будинок Сухоти, Замкова гора, набережна, фонтан Самсона, Гостиний двір, Будинок магістрату, Грецький, Братський та Флоровський монастирі, Успенський собор, церкви: Борисоглібська, Соборна, Пророка Іллі, Воскресіння, Миколая Доброго, Покрови Божої Матері, Петра і Павла, Костянтина та Олени та інші [6, с. 128-201].

3. Плоське, Щекавиця і Оболонь - розповіді про церкви Введення, Йорданську, Кирилівську, околиці Кирилівського монастиря, Дорогожичі, Оболонь та Щекавицю [6, с. 202-217].

4. Сади і Печерськ - розповіді про Купецький та Царський сади, комплекс Києво-Печерської лаври, Аскольдову могилу, Видубицький, Лікарняний, Троїцький та Вознесенський монастирі, Царську, Печерську та Соборну площі, Тріумфальну браму, Звіринець, замок Сімеона Олельковича, пам'ятник Костянтину Острозькому, церкви Різдва Богородиці, Воскресіння Христова, Феодосія Печерського, Дива Архістратига Михаїла, Іоанна Предтечі та інші [6, с. 218-312].

5. Хрещатик, Липки, Нове будівництво та околиці - описи Вишгорода, Межигір'я, Труханового острова, Либеді, Липок, Хрещатика й новобудівель, розташованих між старим містом і Либіддю, зокрема опис Бібіковського бульвару [6, с. 313-346].

Справжньою окрасою путівника стали ілюстрації, що зафіксували історичні об'єкти, котрі не збереглися до наших часів, зокрема Золоті ворота в малюнку 1651 р. [6, с. 12], Михайлівський монастир [6, с. 111], Успенський собор [6, с. 181] тощо.

Вдалим доповненням до путівника К. Широцького стала наукова розвідка $Ф$. Ернста, видана то- вариством "Друкар" 1918 р. [2]. Праця, присвячена архітектурі Києва XVIII ст., містить грунтовні розповіді про майстрів столичного бароко - Й. Шеделя, С. Ковніра, I. Григоровича-Барського. Розвідку було оприлюднено в тогочасному історико-літературному журналі "Наше минуле" i, з метою популяризації історичних знань, згодом надруковано окремим виданням. На думку сучасного історика С. Білоконя, журнал "Наше минуле" віддзеркалював ментальну специфіку лівобережних українців, тісно пов'язаних із російською культурою, й був створений на противагу галицьким виданням М. Грушевського.

Суспільно значущою є й інша праця Ф. Ернста, що побачила світ у київському видавництві "Гуро" 1918 р. [3]. Автор присвятив розвідку художнім скарбам Києва, котрі постраждали внаслідок бойових дій у столиці впродовж 1918 р. Ф. Ернст зауважував, що найбільшої шкоди культурній спадщині міста завдали вуличні бої, котрі точилися впродовж 17-26 січня 1918 р. [3, с. 3]. Значних культурних втрат Київ зазнав і внаслідок вибуху Звіринця 5 червня 1918 р. [3, с. 14] та масштабної пожежі на Подолі 14 червня 1918 р. [3, c. 16]. Через прицільний вогонь більшовицьких гаубиць у січні 1918 р. найбільше постраждали райони Печерська та Старого міста: у Військовий Микільський собор влучило 35 снарядів, знищивши його південний та східний фасади, купол і стелю, старовинний іконостас [3, с. 4]. Під жахливим обстрілом опинилася Лавра (дзвіниця, друкарня, проскурня, Палатна башта). Снаряд розтрощив одну з колон портика в ампірному будинку № 40 на Московській вулиці [3, с. 4]. Великої руйнації зазнали панські маєтки на Липках, Царський палац, єпархіальне училище, кірха [3, с. 6]. У Михайлівську Золотоверху церкву влучило сім снарядів, було зруйновано купол і один зі старовинних вівтарів [3, с. 6]. Стіни Золотих воріт зазнали не менше п'яти гарматних пошкоджень, Андріївська церква - не менше трьох [3, с. 6]. Під густим вогнем опинився Педагогічний музей, де засідала Центральна Рада. Володимирський собор пережив вісім гарматних влучень, внаслідок чого було пошкоджено розпис М. Нестерова "Різдво Христове" [3, с. 8].

25 січня, коли більшовики входили в Київ, гарматний обстріл було спрямовано на будинок М. Грушевського, розташований на вулиці Паньківській. Будівля перетворилася на суцільне вогнище, в якому згоріли унікальні художні зібрання М. Грушевського і В. Кричевського [3, с. 8].

Зокрема, колекція В. Кричевського, котру він збирав упродовж 30 років, налічувала майже 80 старовинних килимів (часів Людовіка XVI, імператриці Слизавети, турецькі, середньоазійські, перські, українські гобелени XVIII ст.), понад 100 одиниць кольорового українського скла (жбани, келихи, вази, миски, чарки, штофи, анімалістичні вироби у вигляді ведмедів, баранів, голубів), майже 500 одиниць української та закордонної кераміки, а також старовинні іграшки. У зібранні зберігалися мідні дошки, котрі гравіював Г. Левицький, старовинні українські портрети. У вогні загинуло 150 картин самого В. Кричевського [3, с. $10-11]$. 
Непоправною втратою стало знищення колекції професора М. Грушевського, що складалася зі 123 килимів, богемського, венеціанського й українського скла, кістяних і срібних виробів, посуду, одягу, меблів, майже 100 одиниць російського, саксонського та українського фарфору, унікальних картин, авторство однісї з яких приписували I. Мазепі [3, с. 12].

Після встановлення радянської влади в Кисві справжнього погрому зазнало зібрання картин М. Терещенка. Ф. Ернст із болем зазначав про розідрані на шматки та понівечені шабельними ударами полотна видатних майстрів (В. Васнецова, I. Шишкіна, В. Сурикова, В. Полєнова, М. Кузнєцова). Окрім того, колекцію було пограбовано: зникло 40 картин російського живопису, 188 етюдів та ескізів В. Верещагіна, гравюра I. Крамського, 3 бронзові статуї та 44 художніх альбоми $[3$, с. 12,14$]$.

Унаслідок страшного вибуху на Звіринці 5 червня 1918 р. значних руйнацій зазнали будівлі Видубицького та Троїцького монастирів, а також Братське кладовище [3, с. $14-15]$. Окремі райони густонаселеного Подолу вигоріли вщент внаслідок пожежі 14 червня 1918 p. $[3$, c. 16$]$

Як наголошує Ф. Ернст, однією з причин руйнації художніх цінностей Києва стало хижацьке ставлення до них з боку Міністерства внутрішніх справ гетьманського уряду. Зокрема, автор 3 обуренням зазначав про брутальне порушення рішення Ради Міністрів про передачу Царського палацу у відомство Міністерства народної освіти. У будівлю було завезено унікальні музейні експонати для подальшого монтажу експозиції Національної картинної галереї поряд iз Воєнно-історичним музеєм, що вже діяв на той час. Утім, керівники гетьманського МВС наказали винести музейне майно на подвір'я, а частину речей взагалі викинути 3 вікон [3, с. 20]. На вулиці цю ганебну "геростратову" справу довершила банальна злива. Згодом понівечені залишки експозиції опинилися у брудному вологому підвалі будівлі Генерального штабу. Засуджуючи дії гетьманських урядовців, Ф. Ернст зауважував, що за нетривале правління більшовиків музей отримав охоронну грамоту і його колекція залишилася неушкодженою [3, с. 20]. Ця констатація стала неабияким виявом авторської об'єктивності, адже саме більшовицьке бомбардування Києва в січні 1918 р. мистецтвознавець назвав найбільшим злочином щодо старовинного міста, а період правління упродовж кінця січня - лютого 1918 р. схарактеризував як "одномісячний каліфат більшовиків" [3, с. 3].

Шкідливим для художніх цінностей Києва, за висловом автора, стало також винищення артефактів минулого "з політичних мотивів". Ф. Ернст зазначав, що у цій справі слід послуговуватися винятково історико-культурним та естетичним критеріями, тож не можна нищити пам'ятники з мотивів "сучасного стану України" [3, с. 18]. Автор наголошував, що за останні півтора року влада в Києві змінювалася шість разів, і якщо кожен новий уряд прагнутиме перекроїти Київ на власний смак i політичний лад, то що залишиться від нещасної столиці ... [3, с. 18]. Як тут не згадати хвилю нещодавнього вандалізму стосовно пам'ятникової спадщини, що так гучно прокотилася містами й селами нашої неньки-України.

Надзвичайно актуальною в контексті сьогодення $€$ праця В. Прокоповича "Київська міліція", що вийшла в першому номері журналу "Наше минуле", а згодом була надрукована окремим накладом [5]. Автор дослідив феномен самоврядного Києва - київську міліцію, яка уособлювала дію Магдебурзького права й була яскравою ознакою міста. Від доби середньовіччя кияни мали право утворювати загони самозахисту на момент скасування Магдебурзького права в Києві налічувалося 2 тис. міліцейської піхоти та 500 кіннотників [5, с. 8]. Загони міліції брали участь у святкових церемоніях міста, зокрема під час Водохрещі, Маковія. Урочистості настільки вражали, що іноземці заздалегідь планували ділові візити саме в ці святкові дні: наприклад, М. Садик-Паша зазначав, що, їдучи на контракт до Києва, прагнув потрапити туди не пізніше 5 січня [5, с. 5]. Тож нещодавно скасована назва правоохоронних органів має глибокий історичний зміст і уособлює багатовікові традиції самоврядування в українських містах, що користувалися таким цивілізаційним здобутком Західної Європи, як Магдебурзьке право. А отже, чи варто було відмовлятися від власної термінології й повертати назву, поширену за царської влади, - питання, на наш погляд, риторичне.

Цікавим для сучасника і вкрай корисним для споживача 1918 р. став кишеньковий довідник "Весь Київ". Окрім великої кількості різноманітної реклами, він містив адреси й номери телефонів керівної верхівки Гетьманату, зокрема й Павла Скоропадського. Фактично, замовивши номер 1-21, будь-який мешканець столиці міг поговорити з Ясновельможним Гетьманом Всєя України [1, с. 1]. Довідник містив координати гетьманського уряду [1, с. $1-2]$, установ Воєнного(!) міністерства [1, с. 3-4] та Міністерства внутрішніх справ [1, с. 4 -6]. Окрім того, було наведено докладну інформацію про міністерства: торгівлі і промисловості [1, с. 6-7], освіти [1, с. 8], юстиції [1, с. 8 -9], праці [1, с. 9], закордонних справ $[1$, с. 10], землеробства [1, с. 11], морське [1, с. 12], шляхів [1, с. 12-13], народного здоров'я [1, с. 13], продовольства [1, с. 14-15], фінансів [1, с. 15-17], сповідань [1, с. 17]. Користувачі довідника мали координати Державної канцелярії гетьмана [1, с. 14], Головного управління пошти і телеграфу [1, с. 17-18]. У виданні перелічено всі громадські установи Києва, що діяли на той момент, зазначено адреси акціонерних товариств, артілей, банків, лікарів, редакцій газет і журналів, художніх і музичних шкіл, ресторанів, майстерень із виготовлення скла, надгробків, штучних зубів тощо. Загалом, довідник, попри кишеньковий формат, відображав повноцінну картину повсякденного життя киянина столітньої давнини.

Висновки. Підсумовуючи викладене, слід зазначити, що, попри революційні події, заколоти, перевороти, жорстоку боротьбу між прибічниками різних таборів громадянської війни, друковані видання 1918 р., присвячені Києву, вирізнялися "мирним" змістом і 
увічнювали історико-культурні здобутки прадавньої столиці українського народу. Водночас автори книгодруків не залишались осторонь від кричущих фактів революційного вандалізму, що призводили до втрати художніх цінностей Києва. Довідникова література часів Гетьманату Павла Скоропадського укладалася за принципами демократичної відкритості й доступності інформації.

\title{
Список використаної літератури
}

1. Весь Киев в кармане. - Киев : Изд-е "Книжник", 1918. — 28 с.

2. Ернст Ф. Київські архитекти XVIII віку / Ф. Ернст. - Київ : Вид. тов-во "Друкар", 1918. — 23 с.

3. Эрнст Ф. Художественные сокровища Киева, пострадавшие в 1918 году / Ф. Эрнст. — Киев : Изд-во "Гуро", 1918. — 20 с.

4. Машкевич С. Киев 1917-1920. Т. 1. Прощание с империей / С. Машкевич. - Киев : Фолио, 2019. - 198 с.

5. Прокопович В. Київська міліція / В. Прокопович. - Київ : Вид. тов-во "Друкар", 1918. — 13 с.

6. Шероцкий К. В. Киев. Путеводитель / К. В. Шероцкий. — Киев : Изд-е В. С. Кульженко, 1918. — 356 с.

\section{Larysa Doiar \\ Kyiv in printed editions 1918}

The presented research is substantively and conceptually related to the studies on the history of Kyiv. Against the backdrop of a critical analysis of the period of the revolutions, the First World War and the Civil Wars, the author reviews the printed publications of 1918 on various aspects of the capital's current life. The article uses books printed in the archives of the Book Chamber of Ukraine. Among the latter are rare books such as a guide to Kiev, compiled by famous Ukrainian historian K. Shyrotsky, scientific works by Ukrainian art historian F. Ernst, and historian V. Prokopovych. These editions state the cultural achievements of Kyiv, demonstrate them in historical retrospect, and actualize the problem of their preservation. The issue of revolutionary vandalism arises with extreme urgency when invaluable works of art, objects of applied art, and original artifacts of everyday life are killed as a result of gunfire and street battles. Drawing on 1918 domestic publications, the author recounts the horrific loss of unique artistic values, including the private collections of M. Hrushevsky and V. Krichevsky. Historical works available in the archival archives reflect the widespread tendency of their popularization among different sections of society at that time. Informative in the context of the development of Kiev studies is a pocket (address-telephone) directory in Kiev in 1918, which presents the colorful and, in fact, full face of the capital, starting with the state authorities and ending with the small issues of the private life of ordinary people of Kiev.

Keywords: historical and cultural reference book; art treasures of Kyiv; private art collections; revolutionary vandalism; traditions of metropolitan self-government; address book

\section{References}

1. Ves Kiev v karmane. (1918). Kiev: Izd-e "Knizhnik".

2. Ernst F. (1918). Kiyivski arhitekti XVIII viku. Kyiv: Vid. tov-vo "Drukar".

3. Ernst F. (1918). Hudozhestvennye sokrovisha Kieva, postradavshie v 1918 godu. Kiev: Izd-vo "Guro".

4. Mashkevich S. (2019). Kiev 1917-1920. T. 1. Proshanie s imperiej. Kiev: Folio.

5. Prokopovich V. (1918). Kiyivska miliciya. Kyiv: Vid. tov-vo "Drukar".

6. Sherockij K. V. (1918). Kiev. Putevoditel. Kiev: Izd-e V. S. Kulzhenko.

\section{ІСТОРИЧНІ РОзВІДКИ}

\author{
УДК 791.43:659.133(477)"1947/1994"]:0.17.1НБУВ(045) \\ DOI: $10.36273 / 2076-9555.2020 .1(282) .48-52$
}

Анжела Шумілова, молодиий науковий співробітник НБУВ, e-mail: AngelaShumil@gmail.com ORCID: https://orcid.org/0000-0003-4731-2346

\section{Украӥнський кіноплакат 1947-1994 років із фондів НБУВ як особливий вид творчості та масової комунікації}

Розглянуто украӥнський кіноплакат 1947-1994 рр. із фондів Наџіональної бібліотеки Украйни імені В. І. Вернадського (НБУВ). Висвітлено результати дослідження історичного розвитку кіноплаката, зокрема особливості та форми створення композичійних сюжетів тощо.

Фонд украйнського тиражного кіноплаката НБУВ налічує понад 3500 примірників, що віддзеркалюють історію розвитку кіномистечтва. Розвиваючи творчий потенчіал, кіноплакат став помітним самостійним явищем і посів провідне місие у сфері пропаганди.

Природа кіноплаката дає змогу розглядати його як соиіально-комунікативний засіб та предмет образотворчого мистеитва, що належить до різних жанрів. Жанр доволі точно відображає актуальність мистецтва, відгук творчих зусиль художсиків на історичні умови та запити часу. Як носій візуальної інформачї в засобах масової комунікації кіноплакат у графічному дизайні постає иілісним художсно-комунікативним явищем. Цей засіб інформації слугує потужсним інструментом впливу на свідомість людини. Розглядаючи плакати, призначені для реклами фільму, дістаємо повнішу інформацію про нього. Кіноплакат у сконцентрованій формі розкриває зміст стрічки, а також відбиває 